\title{
Article \\ Effects of Uremic Clearance Granules in Uremic Pruritus: A Meta-Analysis
}

\author{
Ping-Hsun Lu ${ }^{1,2} \mathbb{D}$, Jen-Yu Wang ${ }^{3,4}$, Hui-En Chuo ${ }^{4}$ and Po-Hsuan Lu ${ }^{4,5, * \mathbb{D}}$ \\ 1 Department of Chinese Medicine, Taipei Tzu Chi Hospital, Buddhist Tzu Chi Medical Foundation, \\ New Taipei City 23142, Taiwan; 101318121@gms.tcu.edu.tw \\ 2 School of Post-Baccalaureate Chinese Medicine, Tzu Chi University, Hualien 97048, Taiwan \\ 3 MacKay Junior College of Medicine, Nursing, and Management, New Taipei City 11260, Taiwan; \\ jyw.6993@mmh.org.tw \\ 4 Department of Dermatology, MacKay Memorial Hospital, Taipei 10449, Taiwan; \\ waynec.4204@mmh.org.tw \\ 5 Department of Medicine, MacKay Medical College, New Taipei City 252005, Taiwan \\ * Correspondence: pohsuanlu.4217@mmh.org.tw; Tel.: +886-2-25433535\#2556
}

check for updates

Citation: Lu, P.-H.; Wang, J.-Y.; Chuo, H.-E.; Lu, P.-H. Effects of Uremic Clearance Granules in Uremic Pruritus: A Meta-Analysis. Toxins 2021, 13, 702. https://doi.org/ $10.3390 /$ toxins 13100702

Received: 6 September 2021

Accepted: 1 October 2021

Published: 4 October 2021

Publisher's Note: MDPI stays neutral with regard to jurisdictional claims in published maps and institutional affiliations.

Copyright: (c) 2021 by the authors. Licensee MDPI, Basel, Switzerland. This article is an open access article distributed under the terms and conditions of the Creative Commons Attribution (CC BY) license (https:// creativecommons.org/licenses/by/ $4.0 /)$.

\begin{abstract}
Uremic pruritus is common among patients with advanced or end-stage renal disease, with an incidence of $>40 \%$ among patients on dialysis. Uremic clearance granules (UCGs) are effective in managing uremic pruritus and delay the progression of chronic kidney disease. We conducted a systematic review and a meta-analysis to evaluate the efficacy of UCG in patients with uremic pruritus. Several electronic databases were searched systematically from their inceptions until 19 July 2021. Randomized control trials evaluating the efficacy of UCG in patients with uremic pruritus were selected. Eleven trials including 894 participants were published between 2011 and 2021. Patients administered UCGs had a significantly decreased visual analog scale score (mean difference [MD], $-2.02 ; 95 \%$ confidence interval [CI], -2.17 to -1.88 ), serum levels of hsCRP (MD, $-2.07 \mathrm{mg} / \mathrm{dL} ; 95 \%$ $\mathrm{CI},-2.89$ to $-1.25 ; p<0.00001)$, TNF- $\alpha$ (MD, $-15.23 \mathrm{mg} / \mathrm{L} ; 95 \% \mathrm{CI},-20.00$ to $-10.47 ; p<0.00001])$, 32-MG (MD, $-10.18 \mathrm{mg} / \mathrm{L} ; 95 \% \mathrm{CI},-15.43$ to $-4.93 ; p<0.00001$ ), and IL-6 (MD, $-6.13 \mathrm{mg} / \mathrm{L} ; 95 \% \mathrm{CI}$, -7.42 to $-4.84 ; p<0.00001)$. In addition, UCGs significantly reduced serum levels of creatinine, BUN, $\mathrm{PTH}$, iPTH, phosphorus, and the overall effectiveness rate. UCGs could be an attractive complementary therapy for patients with uremic pruritus.
\end{abstract}

Keywords: uremic clearance granules; chronic kidney disease; uremic pruritus; inflammatory biomarkers; mineral metabolism

Key Contribution: This article is the first meta-analysis of using traditional Chinese medicine to treat uremic pruritus and demonstrates that UCGs could be an attractive complementary therapy for patients with uremic pruritus.

\section{Introduction}

Uremic pruritus (UP) is a distressing complication in patients with end-stage renal disease (ESRD) and on dialysis, either hemodialysis (HD) or peritoneal dialysis (PD) [1]. Aside from generalized pruritus, UP causes sleep disturbance, depression, poor quality of life, and increased mortality risk [2,3]. Several markers have been reported to be associated with UP. Conventionally, dialysis efficiency and mineral metabolism markers, for example, phosphorus $(\mathrm{P})$, calcium $(\mathrm{Ca})$, parathyroid hormone $(\mathrm{PTH})$, and intact parathyroid hormone (iPTH) levels, were thought to be associated with increased risk of UP [4-6]. Recently, UP has been considered a systemic inflammatory disease. The association of inflammatory markers, such as C-reactive protein (CRP), interleukin-6 (IL-6), interleukin-2 (IL-2), $\beta 2$-microglobulin ( $\beta 2-\mathrm{MG})$, and tumor necrosis factor- $\alpha$ (TNF- $\alpha$ ) with UP has been confirmed [7-9]. Therapies for UP include systemic treatments, topical treatment, and 
complementary alternative medicine $[3,10,11]$. Furthermore, only a few meta-analyses on the use of treatment agents such as gabapentin and nalfurafine with some adverse effects exist $[10,11]$. Although the use of acupressure has also been reported, the evidence is insufficient [12]. Since Chinese herbal bath therapy depletes body fluids, it is unsuitable for weak patients [13]. Hence, identifying complementary therapies for UP with fewer adverse effects is critical.

Studies have reported the benefits of oral and topical application of traditional Chinese medicine (TCM) in UP $[13,14]$. Uremic clearance granules (UCGs) (Consun Pharmaceutical Group), or NiaoDuQing, were developed based on TCM principles and have been widely used for $>20$ years to treat chronic kidney disease (CKD) [15]. UCGs are the first TCM agents to be approved for CKD treatment by the China Food and Drug Administration (National Medicine Permit No. Z20073356) [16]. According to the TCM theory, UP is a yin deficiency of the kidney and spleen, which causes dampness and toxin accumulation. Furthermore, yin deficiency produces heat and blood deficiency produces wind. The UP syndrome, according to TCM, involves dampness, toxins, wind, fire, and stasis, which interact with each other during UP $[17,18]$. The prescription for UCG in TCM includes 16 herbs, such as Danshen, Gancao, Huangqi, Fuling, Kushen, Juhua, and so forth (Table 1) [19,20]. These herbs contain various biologically active compounds such as salvianolic acid A, paeoniflorin, emodin, isoflavone, and astragaloside IV [21]. These compounds show synergistic effects to improve renal function, including lowering blood urea nitrogen (BUN) and serum creatinine (Scr) levels [15]. balancing the $\mathrm{Ca}$ and P metabolic dysfunction [22]. improving the systemic microinflammatory state [23], and reducing the severity of UP [24]. In this study, we performed a systematic literature review and meta-analysis of eligible randomized controlled trials (RCTs) to evaluate the efficacy of UCG in the management of UP.

Table 1. Overview ingredients of UCG.

\begin{tabular}{|c|c|c|c|c|}
\hline Chinese Name & English/Latin Name & Family & Species & $\begin{array}{l}\text { Prescription Functions } \\
\text { (TCM Patterns) }\end{array}$ \\
\hline Dahuang & $\begin{array}{l}\text { Rheum palmatum/Rheum } \\
\text { officinale }\end{array}$ & Polygonaceae & R. officinale & $\begin{array}{l}\text { To drain heat, cool blood, } \\
\text { resolve toxins, and expel } \\
\text { stasis }\end{array}$ \\
\hline Gancao & $\begin{array}{c}\text { Glycyrrhiza } \\
\text { inflata/Glycyrrhiza uralensis }\end{array}$ & Fabaceae & G. uralensis & $\begin{array}{l}\text { To supplement center and } \\
\text { boost qi, drain fire, and } \\
\text { resolve toxins }\end{array}$ \\
\hline Chaihu & $\begin{array}{l}\text { Bupleurum scorzoneri- } \\
\text { folium/Bupleurum } \\
\text { chinense }\end{array}$ & Apiaceae & - & $\begin{array}{l}\text { To harmonize exterior and } \\
\text { interior }\end{array}$ \\
\hline Huangqi & $\begin{array}{c}\text { Astragalus } \\
\text { mongholicus/Astragalus } \\
\text { membranaceus }\end{array}$ & Fabaceae & - & $\begin{array}{l}\text { To boost qi and secure } \\
\text { exterior, and draw toxins }\end{array}$ \\
\hline Sangbaipi & $\begin{array}{l}\text { White Mulberry Root/Morus } \\
\text { alba }\end{array}$ & Moraceae & M. alba & $\begin{array}{l}\text { To disinhibit water and } \\
\text { disperse edema }\end{array}$ \\
\hline Dangshen & $\begin{array}{c}\text { Codonopsis } \\
\text { tangshen/Codonopsis pilosula }\end{array}$ & Campanulaceae & C. pilosula & $\begin{array}{l}\text { To fortify the spleen and } \\
\text { supplement lung, boost qi, } \\
\text { and engender liquid }\end{array}$ \\
\hline Baishao & $\begin{array}{c}\text { Common Peony/Paeonia } \\
\text { lactiflora }\end{array}$ & Paeoniaceae & P. lactiflora & $\begin{array}{l}\text { To calm the liver and relieve } \\
\text { pain, nourish the blood and } \\
\text { constrain yin }\end{array}$ \\
\hline Chuanxiong & $\begin{array}{c}\text { Cnidium } \\
\text { officinale/Ligusticum } \\
\text { chuanxiong }\end{array}$ & Apiaceae & L. chuanxiong & $\begin{array}{l}\text { To move qi, quicken the } \\
\text { blood, and dispel wind }\end{array}$ \\
\hline Kushen & $\begin{array}{c}\text { Light yellow } \\
\text { Sophora/Sophora flavescens }\end{array}$ & Fabaceae & S. flavescens & $\begin{array}{l}\text { To clear heat and dry damp, } \\
\text { dispel wind, and kill worms }\end{array}$ \\
\hline Juhua & $\begin{array}{c}\text { Florists Chrysanthemum } \\
\text { Flower/Chrysanthemum } \\
\text { morifolium }\end{array}$ & Asteraceae & C. morifolium & $\begin{array}{l}\text { To dispel wind, clear heat, } \\
\text { and resolve toxins }\end{array}$ \\
\hline
\end{tabular}


Table 1. Cont.

\begin{tabular}{|c|c|c|c|c|}
\hline Chinese Name & English/Latin Name & Family & Species & $\begin{array}{c}\text { Prescription Functions (TCM } \\
\text { Patterns) }\end{array}$ \\
\hline Banxia & Ternate Pinellia/Pinellia ternata & Araceae & P. ternata & $\begin{array}{l}\text { To eliminate damp, resolve } \\
\text { cold phlegm, and dissipate } \\
\text { binds }\end{array}$ \\
\hline Baizhu & $\begin{array}{c}\text { Large head } \\
\text { Atractylodes/Atractylodes } \\
\text { macrocephala }\end{array}$ & Asteraceae & A. macrocephala & $\begin{array}{l}\text { To boost qi, fortify the spleen, } \\
\text { dry damp, and disinhibit water }\end{array}$ \\
\hline Fuling & Indian Bread/Poria cocos & Fomitopsidaceae & W. $\operatorname{cocos}$ & $\begin{array}{l}\text { To disinhibit water, percolate } \\
\text { dampness, fortify the spleen, } \\
\text { and quiet the heart }\end{array}$ \\
\hline Heshouwu & $\begin{array}{l}\text { Tuber Fleeceflower/Polygonum } \\
\text { multiflorum }\end{array}$ & Polygonaceae & F. multiflora & $\begin{array}{l}\text { To enrich yin, nourish the } \\
\text { blood, moisten intestines to } \\
\text { free stool, dispel wind, and } \\
\text { resolve toxins }\end{array}$ \\
\hline Danshen & $\begin{array}{c}\text { Salvia przewalskii/Salviae } \\
\text { Miltiorrhizae }\end{array}$ & Lamiaceae & S. miltiorrhiza & $\begin{array}{l}\text { To quicken the blood, dispel } \\
\text { stasis, nourish the blood, quiet } \\
\text { the spirit, cool the blood, and } \\
\text { disperse welling abscess }\end{array}$ \\
\hline Cheqiancao & $\begin{array}{l}\text { All-grass of Rippleseed } \\
\text { plantain/Herba Plantaginis }\end{array}$ & Plantaginaceae & P. asiatica & $\begin{array}{l}\text { Treatment of edema with } \\
\text { oliguria, urinary infection with } \\
\text { difficult painful urination }\end{array}$ \\
\hline
\end{tabular}

$\mathrm{TCM}=$ traditional Chinese medicine; $\mathrm{UCG}=$ uremic clearance granule .

\section{Results}

\subsection{Study Characteristics}

The described search strategy yielded 228 articles (five English, three Chinese; 24 duplicate studies were excluded). After screening the title and abstract, we excluded 177 articles per our study selection criteria earlier. Full texts of the remaining 27 articles were reviewed; 16 articles were excluded for the following reasons: four were review articles [25-28], four applied a different intervention [29-32], seven did not include patients with UP [15,33-38], and one was a retrospective study [39]. Finally, 11 RCTs were included in the meta-analysis (Figure 1) [24,40-49].

The basic characteristics of the 11 RCTs published between 2012 and 2021 are listed in Table 2 and Table S1. A total of 894 participants were enrolled, with the sample size ranging from 32 to 128. All included studies were RCTs that recruited patients with UP experiencing itching and on maintenance HD; most participants were adults. The patients received HD combined with hemoperfusion (HP) in two trials [45,47] and HD combined with Caltrate D600 and Calcitriol in one [41]. All these trials were included in our meta-analysis as they met the inclusion criteria. 


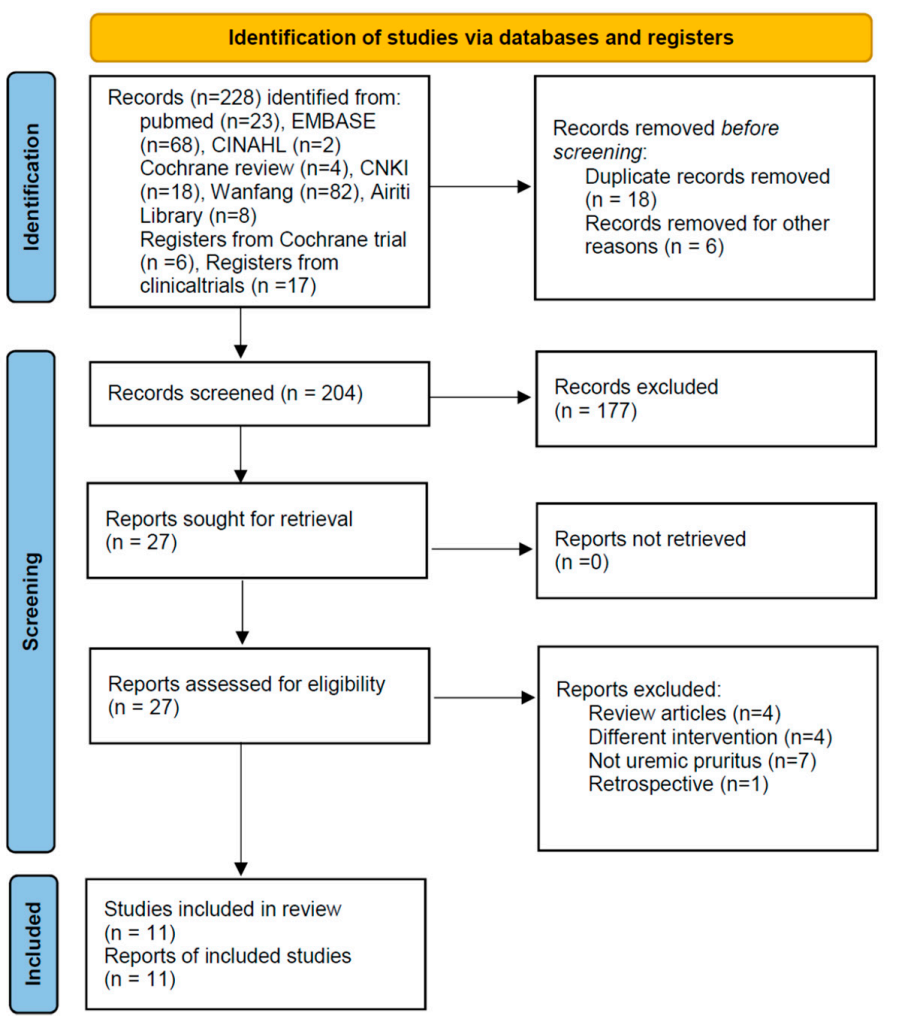

Figure 1. PRISMA 2020 Flow Diagram.

Table 2. Characteristics of Selected Studies.

\begin{tabular}{|c|c|c|c|c|c|c|c|c|c|}
\hline Study (Year) & $\begin{array}{l}\text { Study } \\
\text { Design }\end{array}$ & $\begin{array}{c}\text { Inclusion } \\
\text { Criteria }\end{array}$ & $\begin{array}{l}\text { No. of } \\
\text { Patients }\end{array}$ & Age (Years) & $\begin{array}{c}\text { Route, } \\
\text { Dosage, and } \\
\text { Frequency }\end{array}$ & Duration & Inspection Data & $\begin{array}{c}\text { Pruritus } \\
\text { Severity } \\
\text { Assessment }\end{array}$ & $\begin{array}{c}\text { Pruritus Score } \\
\text { (Before } \rightarrow \text { After), }\end{array}$ \\
\hline $\begin{array}{l}\text { Kao et al. } \\
2012 \text { [49] }\end{array}$ & $\mathrm{RCT}$ & HD + HP & $\begin{array}{l}\text { U: } 16 \\
\text { C: } 16\end{array}$ & $\begin{array}{l}25-74 \\
25-74\end{array}$ & $\begin{array}{l}\text { Enema, } 15 \mathrm{~g}, \\
2 \text { times } / \mathrm{d}\end{array}$ & $18 \mathrm{M}$ & $\begin{array}{c}\text { overall } \\
\text { effectiveness }\end{array}$ & Duo PS & $\begin{array}{c}\mathrm{U}: 29.18(1.52) \rightarrow \\
12.69(3.16) \\
\mathrm{C}: 26.54(4.03) \rightarrow \\
17.13(3.24)\end{array}$ \\
\hline $\begin{array}{l}\text { Yang et al. } \\
2016 \text { [47] }\end{array}$ & RCT & $\begin{array}{c}\mathrm{U}: \mathrm{HD}+\mathrm{HP} \\
(14) ; \\
\mathrm{HD}(7) \\
\text { C: HD + HP } \\
\text { (11); HD (10) }\end{array}$ & $\begin{array}{l}\mathrm{U}: 21 \\
\mathrm{C}: 21\end{array}$ & $\begin{array}{c}\text { U: } \\
51.48(13.49) \\
\text { C: } \\
51.67(11.68)\end{array}$ & $\begin{array}{l}\text { Oral, } 2.5 \mathrm{~g}, 2 \\
\text { times } / \mathrm{d}\end{array}$ & $1 \mathrm{M}$ & $\begin{array}{c}\text { Ca, P, PTH, Scr, } \\
\text { BUN, UA, FGF23, } \\
\text { CRP, overall } \\
\text { effectiveness }\end{array}$ & Kuypers PS & $\begin{array}{c}\text { U: } 11.57(2.45) \\
\rightarrow 6.43(3.02) \\
\text { C: } 11.67(4.98) \rightarrow \\
11.86(4.33)\end{array}$ \\
\hline $\begin{array}{l}\text { Yu et al. } \\
2017 \text { [48] }\end{array}$ & RCT & HD & $\begin{array}{l}\text { U: } 65 \\
\text { C: } 63\end{array}$ & $\begin{array}{l}\mathrm{U}: 35-68 \\
\mathrm{C}: 36-70\end{array}$ & $\begin{array}{l}\text { Oral, } 5 \mathrm{~g}, 4 \\
\text { times/d }\end{array}$ & $3 \mathrm{M}$ & $\begin{array}{c}\text { Ca, P, PTH, } \\
\beta 2-M G, \text { hs-CRP, } \\
\text { overall } \\
\text { effectiveness }\end{array}$ & VAS & 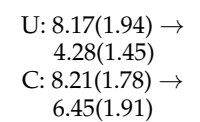 \\
\hline $\begin{array}{l}\text { Sun et al. } \\
2018 \text { [44] }\end{array}$ & RCT & $\mathrm{HD}$ & $\begin{array}{l}\text { U: } 54 \\
\text { C: } 54\end{array}$ & $\begin{array}{c}\text { U: } \\
54.12(5.78) \\
\text { C: } \\
54.08(6.23)\end{array}$ & $\begin{array}{l}\text { Oral, } 2.5 \mathrm{~g}, 2 \\
\text { times } / \mathrm{d}\end{array}$ & - & $\begin{array}{c}\text { Scr, BUN, UA, } \\
\text { hs-CRP, IL-6, } \\
\text { TNF- } \alpha, \text { Alb, Hb }\end{array}$ & PS1 & $\begin{array}{c}\mathrm{U}: 11.56(3.02) \rightarrow \\
5.12(0.89) \\
\mathrm{C}: \begin{array}{c}11.89(3.12) \\
8.28(2.02)\end{array} \rightarrow\end{array}$ \\
\hline $\begin{array}{l}\text { Tan et al. } \\
2018 \text { [45] }\end{array}$ & RCT & $\mathrm{HD}+\mathrm{HP}$ & $\begin{array}{l}\text { U: } 40 \\
\text { C: } 40\end{array}$ & $\begin{array}{c}\text { U: } \\
48.83(8.95) \\
\text { C: } \\
48.92(3.87)\end{array}$ & $\begin{array}{l}\text { Oral, } 5 \mathrm{~g}, 4 \\
\text { times/d }\end{array}$ & $3 \mathrm{M}$ & $\begin{array}{c}\text { Ca, P, PTH, Scr, } \\
\text { BUN, UA, IL-6, } \\
\text { TNF- } \alpha, \text { hs-CRP, } \\
\text { overall } \\
\text { effectiveness }\end{array}$ & PS2 & $\begin{array}{c}\text { U: } 8.37(0.89) \rightarrow \\
4.6(0.38) \\
\text { C: } 8.14(0.96) \rightarrow \\
6.44(0.55)\end{array}$ \\
\hline $\begin{array}{l}\text { Cao et al. } \\
2019 \text { [40] }\end{array}$ & $\mathrm{RCT}$ & HD & $\begin{array}{l}\text { U: } 40 \\
\text { C: } 40\end{array}$ & $\begin{array}{l}\text { U: } 59.7 \\
\text { C: } 59.8\end{array}$ & $\begin{array}{l}\text { Oral, } 5 \mathrm{~g}, 4 \\
\text { times/d }\end{array}$ & $2 \mathrm{M}$ & $\begin{array}{l}\text { hs-CRP, overall } \\
\text { effectiveness }\end{array}$ & NRS & $\begin{array}{c}\mathrm{U}: 7.89(1.31) \rightarrow \\
3.10(0.93) \\
\mathrm{C}: \begin{array}{c}7.95(1.43) \rightarrow \\
5.37(1.02)\end{array}\end{array}$ \\
\hline $\begin{array}{l}\text { Kuo et al. } \\
2019[41]\end{array}$ & $\mathrm{RCT}$ & $\begin{array}{l}\mathrm{HD}+\mathrm{Ca}+ \\
\text { Calcitriol }\end{array}$ & $\begin{array}{l}\mathrm{U}: 30 \\
\mathrm{C}: 30\end{array}$ & $\begin{array}{l}\mathrm{U}: 42.6(3.2) \\
\mathrm{C}: 41.9(3.4)\end{array}$ & $\begin{array}{l}\text { Oral, } 5 \mathrm{~g}, 4 \\
\text { times/d }\end{array}$ & $3 \mathrm{M}$ & $\begin{array}{c}\text { Ca, P, PTH, } \\
\text { overall } \\
\text { effectiveness }\end{array}$ & - & - \\
\hline
\end{tabular}


Table 2. Cont.

\begin{tabular}{|c|c|c|c|c|c|c|c|c|c|}
\hline Study (Year) & $\begin{array}{l}\text { Study } \\
\text { Design }\end{array}$ & $\begin{array}{l}\text { Inclusion } \\
\text { Criteria }\end{array}$ & $\begin{array}{l}\text { No. of } \\
\text { Patients }\end{array}$ & Age (Years) & $\begin{array}{c}\text { Route, } \\
\text { Dosage, and } \\
\text { Frequency }\end{array}$ & Duration & Inspection Data & $\begin{array}{c}\text { Pruritus } \\
\text { Severity } \\
\text { Assessment }\end{array}$ & $\begin{array}{c}\text { Pruritus Score } \\
\text { (Before } \rightarrow \text { After), }\end{array}$ \\
\hline $\begin{array}{l}\text { Kun et al. } \\
2019 \text { [42] }\end{array}$ & $\mathrm{RCT}$ & HD & $\begin{array}{l}\text { U: } 23 \\
\text { C: } 23\end{array}$ & $\begin{array}{l}\text { U:45.3(5.3) } \\
\text { C:46.1(4.9) }\end{array}$ & $\begin{array}{l}\text { Oral, } 5 \mathrm{~g}, 4 \\
\text { times/d }\end{array}$ & $3 \mathrm{M}$ & $\begin{array}{c}\text { overall } \\
\text { effectiveness }\end{array}$ & VAS & $\begin{array}{c}\mathrm{U}: 8.13(1.77) \rightarrow \\
4.73(1.41) \\
\mathrm{C}: 8.40(2.07) \rightarrow \\
6.28(2.19)\end{array} \rightarrow$ \\
\hline $\begin{array}{l}\text { Li et al. } \\
2019 \text { [43] }\end{array}$ & RCT & $\mathrm{HD}$ & $\begin{array}{l}\text { U: } 52 \\
\text { C: } 50\end{array}$ & $\begin{array}{l}\text { U: } 47.2(3.7) \\
\text { C: } 46.7(4.2)\end{array}$ & $\begin{array}{l}\text { Oral, } 5 \mathrm{~g}, 4 \\
\text { times } / \mathrm{d}\end{array}$ & $3 \mathrm{M}$ & $\begin{array}{c}\text { Ca, P, PTH, } \\
\beta 2-\mathrm{MG}, \text { hs-CRP, } \\
\text { overall } \\
\text { effectiveness }\end{array}$ & VAS & $\begin{array}{c}\mathrm{U}: 8.18(1.69) \rightarrow \\
4.31(1.52) \\
\mathrm{C}: 8.20(1.96) \rightarrow \\
6.38(1.88)\end{array}$ \\
\hline \multirow[t]{2}{*}{$\begin{array}{l}\text { Chen et al. } \\
2020 \text { [24] }\end{array}$} & \multirow[t]{2}{*}{$\mathrm{RCT}$} & \multirow[t]{2}{*}{ HD } & \multirow[t]{2}{*}{$\begin{array}{l}\text { U: } 50 \\
\text { C: } 50\end{array}$} & \multirow[t]{2}{*}{$\begin{array}{l}\text { U:65.72(10.33) } \\
\text { C:64.12(10.54) }\end{array}$} & \multirow[t]{2}{*}{$\begin{array}{l}\text { Oral, } 5 \mathrm{~g}, 4 \\
\text { times } / \mathrm{d}\end{array}$} & \multirow[t]{2}{*}{$3 \mathrm{M}$} & \multirow[t]{2}{*}{$\begin{array}{c}\text { Ca, P, PTH, SCr, } \\
\text { BUN, } \beta 2-\mathrm{MG}, \\
\text { overall } \\
\text { effectiveness, } \\
\text { ADR }\end{array}$} & VAS & $\begin{array}{c}\mathrm{U}: 7.62(1.02) \rightarrow \\
3.36(1.06) \\
\mathrm{C}: 7.54(0.98) \rightarrow \\
5.53(1.78)\end{array}$ \\
\hline & & & & & & & & DLQI & $\begin{array}{c}\mathrm{U}: 17.37(3.56) \rightarrow \\
6.44(1.59) \\
\mathrm{C}: 16.98(3.72) \rightarrow \\
10.82(2.31) \\
\mathrm{U}: 21.84(5.53) \rightarrow \\
8.36(2.21) \\
\mathrm{C}: 21.54(5.70) \rightarrow \\
10.55(3.88)\end{array} \rightarrow$ \\
\hline Xi 2020 [46] & $\mathrm{RCT}$ & HD & $\begin{array}{l}\text { U: } 58 \\
\text { C: } 58\end{array}$ & $\begin{array}{c}\text { U: } \\
47.88(3.52) \\
\text { C: } \\
47.79(3.41)\end{array}$ & $\begin{array}{l}\text { Oral, } 5 \mathrm{~g}, 4 \\
\text { times/d }\end{array}$ & - & $\begin{array}{c}\text { P, PTH, } \beta 2-\mathrm{MG}, \\
\text { hs-CRP, overall } \\
\text { effectiveness }\end{array}$ & VAS & 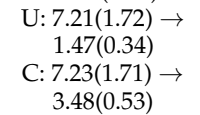 \\
\hline
\end{tabular}

5-DIS = 5-dimensional itching scale; $\mathrm{ADR}=$ adverse drug reaction; $\mathrm{Alb}=$ albumin; $\mathrm{BUN}=$ blood urea nitrogen; $\mathrm{C}=\mathrm{control}$ group; Ca = calcium; $\mathrm{d}=$ day; DLQI = dermatology life quality index; FGF23 = fibroblast growth factor 23; Hb = hemoglobin; HD = hemodialysis; HP = hemoperfusion; hs$\mathrm{CRP}=$ high-sensitivity $\mathrm{C}$-reactive protein; IL-6 = interleukin-6; $\beta 2-\mathrm{MG}=\beta 2$-microglobulin; $\mathrm{M}=$ month; NRS = numeric rating scale; $\mathrm{P}=$ phosphorus; PS = pruritus scale; PTH = parathyroid hormone; RCT = randomized controlled trial; Scr $=$ serum creatinine; TNF- $\alpha=$ tumor necrosis factor- $\alpha$; $\mathrm{U}=$ uremic clearance granule group; $\mathrm{UA}=$ uric acid; $\mathrm{UCG}=$ uremic clearance granule group; VAS = visual analog scale.

Risk of bias was assessed per the recommendations of RoB 2 (revised tool to assess the risk of bias in randomized trials; latest revision, 22 August 2019), as shown in Figure 2. Random allocation was applied in all included trials, but none offered information about the concealed allocation sequences. With regard to randomization, three trials followed the visit order $[40,45,49]$, seven studies used a randomization table [24,42-44,46-48], and one study used random sampling [40]. One study provided no information on baseline characteristics [47]. Double blinding was not used in any trial, and an intention-to-treat analysis with an acceptable loss-to-follow-up rate $(<5 \%)$ was used. Approximately all the outcome data were available in the included trials. The outcome measurement bias for the primary outcomes, visual analog scale (VAS), and overall effectiveness rate, was high because these were reported by the participants. The outcome measurement bias for the secondary outcomes was low as these laboratory data were not affected by patient blinding. 


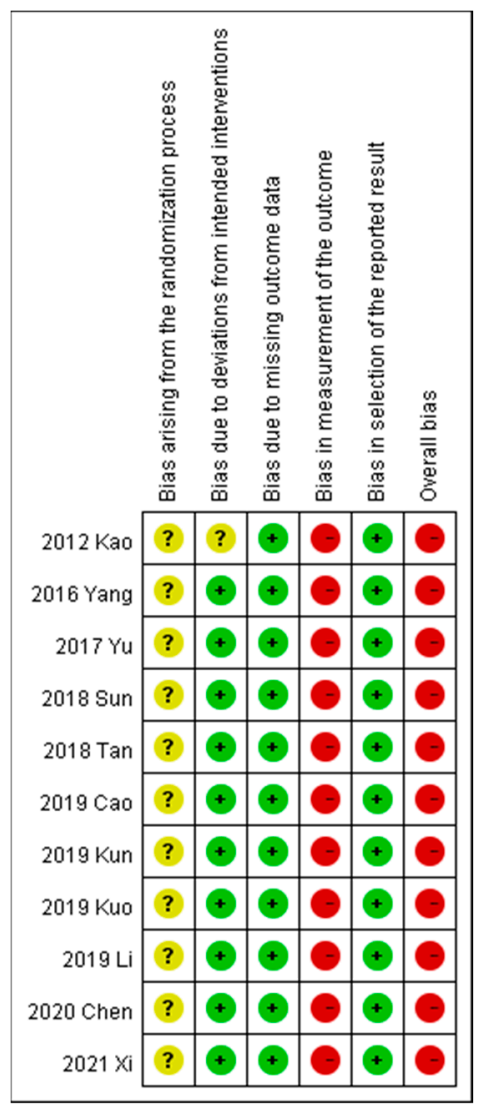

Figure 2. Risk of bias in different studies.

\subsection{Primary Outcomes}

A meta-analysis of the five trials scoring pruritus using the VAS showed that the VAS score decreased significantly after UCG administration (mean difference [MD], $-2.02 ; 95 \%$ $\mathrm{CI},-2.17$ to -1.88$]$. Heterogeneity across the trials was not significant $\left(I^{2}=0 \% ; p<0.00001\right.$; Figure 3). A meta-analysis of the night trials using itch scales (Dirk R. Kuypers, Duo, and Mettang, or 5-D itch scale) showed that the overall effectiveness in the UCG group was significantly higher than that in the placebo group (odds ratio [OR], 3.16; 95\% CI, 2.14-4.67). Heterogeneity across trials was not significant $\left(I^{2}=0 \% ; p<0.00001\right.$; Figure 4$)$.

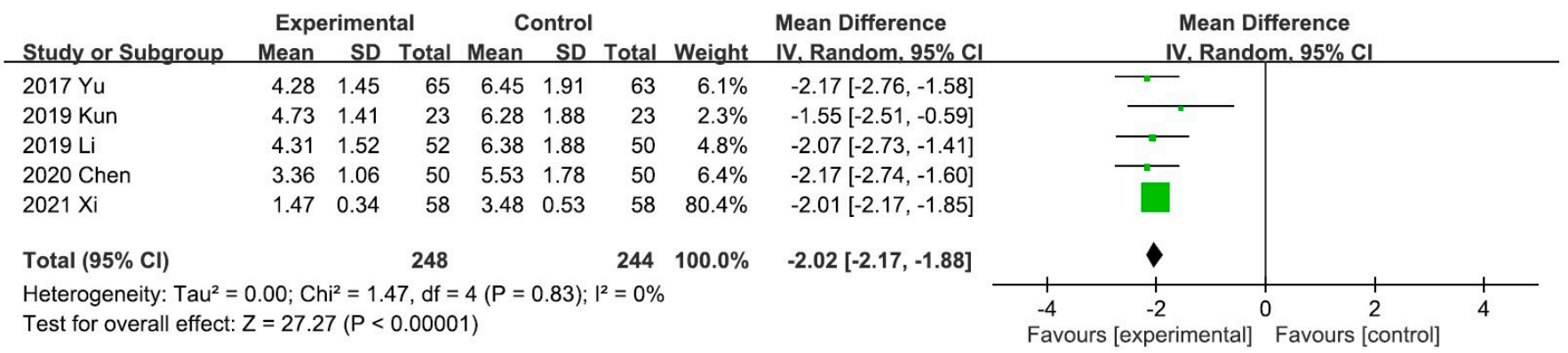

Figure 3. Forest plot for comparison of the visual analog scale in patients with uremic pruritus treated with uremic clearance granules. CI, confidence interval. 


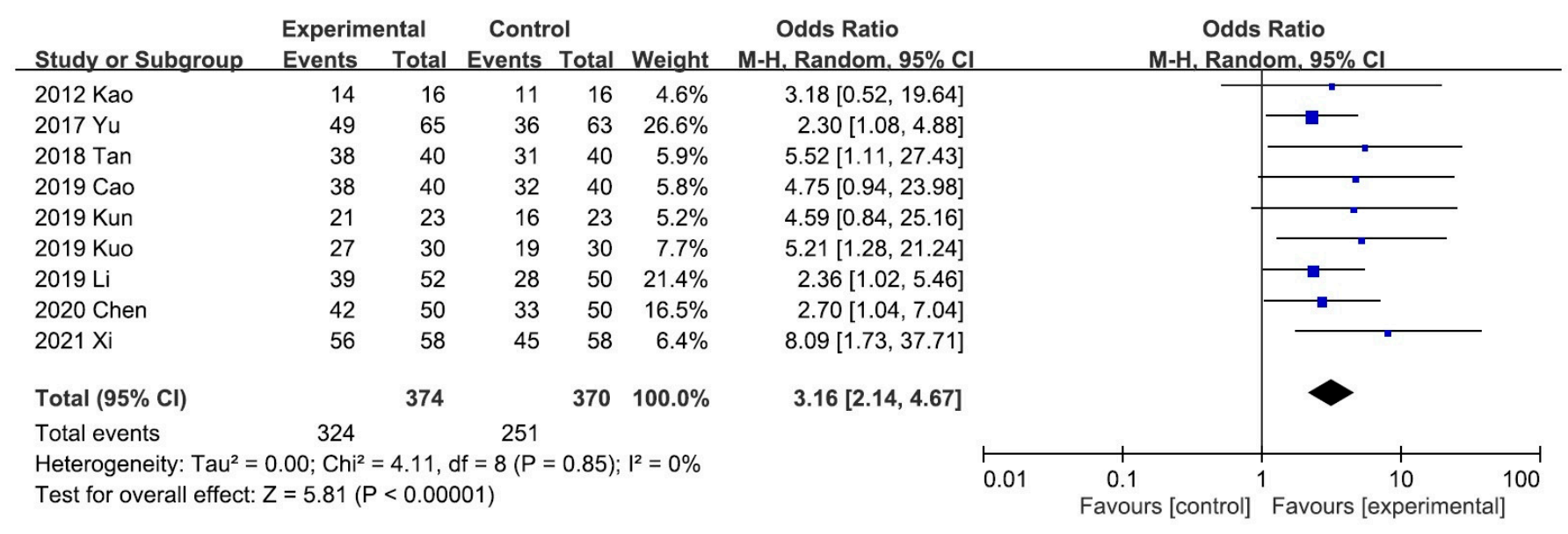

Figure 4. Forest plot for comparison of the overall effectiveness in patients with uremic pruritus treated with uremic clearance granules. CI, confidence interval.

\subsection{Secondary Outcomes}

2.3.1. Effect of UCG on Serum Levels of $\mathrm{Ca}, \mathrm{P}, \mathrm{PTH}$, and iPTH

In Figure 5, the effect of UCG supplementation on $\mathrm{Ca}, \mathrm{P}, \mathrm{PTH}$, and iPTH serum levels was assessed as follows: serum level of $\mathrm{Ca}$ in six, P in seven, PTH in five, and PTH in two trials. Results of our meta-analyses revealed that UCG supplementation significantly decreased the serum P level (MD, $-0.32 \mathrm{mmol} / \mathrm{L} ; 95 \% \mathrm{CI},-0.41$ to $-0.24 ; p<0.00001)$, PTH $(\mathrm{MD},-93.03 \mathrm{ng} / \mathrm{L} ; 95 \% \mathrm{CI},-141.91$ to $-44.14 ; p=0.0002)$, and $\mathrm{PPTH}(\mathrm{MD},-89.51 \mathrm{mmol} / \mathrm{L}$; $95 \%$ CI,-123.95 to $-55.07 ; p<0.00001$ ), but not Ca (MD, $0.08 \mathrm{mmol} / \mathrm{L} ; 95 \% \mathrm{CI},-0.26$ to $-0.43 ; p=0.64)$. Heterogeneity across trials was high for $\mathrm{Ca}, \mathrm{PTH}, \mathrm{iPTH}$, and $\mathrm{P}(\mathrm{Ca}$ : $I^{2}=99 \% ; p<0.00001$; PTH: $I^{2}=95 \% ; p<0.00001$; iPTH: $I^{2}=72 \% ; p=0.06 ;$ P: $I^{2}=66 \%$; $p=0.007)$. 


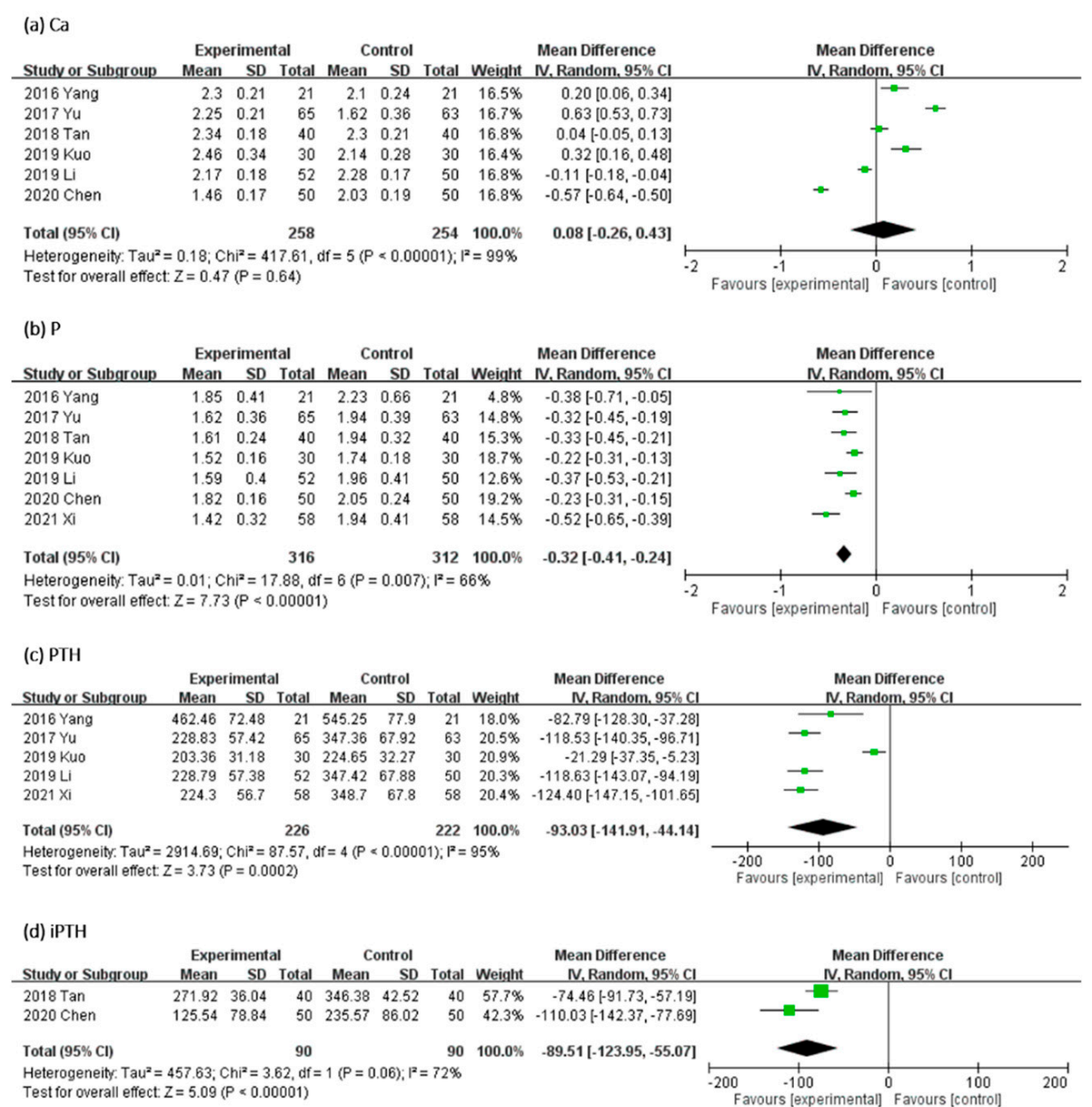

Figure 5. Forest plot for comparison of the serum level of (a) Calcium (Ca), (b) Phosphorus (P), (c) parathyroid hormone (PTH), and (d) intact parathyroid hormone (iPTH) in patients with uremic pruritus treated with uremic clearance granules. CI, confidence interval.

\subsubsection{Effect of UCG on SCr, BUN, and Uric Acid Levels}

In Figure 6, the effect of UCG supplementation on SCr and BUN was assessed in four trials and of uric acid (UA) in three RCTs. Results of our meta-analyses revealed that UCG supplementation significantly decreased the Scr level (MD, $-128.38 \mu \mathrm{mol} / \mathrm{L} ; 95 \% \mathrm{CI}$, -214.34 to $-42.42 ; p=0.003)$ and BUN level (MD, $-5.23 \mathrm{mmol} / \mathrm{L} ; 95 \% \mathrm{CI},-5.87$ to -4.58 ; $p<0.00001$ ) but not the UA level (MD, $-16.94 \mu \mathrm{mol} / \mathrm{L} ; 95 \% \mathrm{CI},-63.56$ to $29.67 ; p=0.48$ ). The heterogeneity across trials was high for Scr $\left(I^{2}=99 \% ; p<0.00001\right)$ and UA $\left(I^{2}=97 \%\right.$; $p<0.00001)$; however, heterogeneity for BUN was not significant $\left(I^{2}=0 \% ; p=0.47\right)$. 
(a) $\mathrm{SCr}$

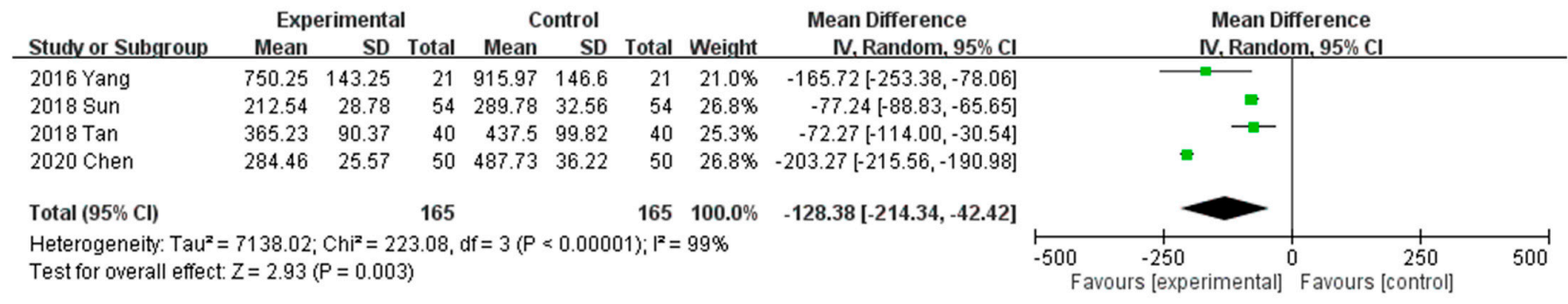

(b) BUN

\begin{tabular}{|c|c|c|c|c|c|c|c|c|c|c|}
\hline \multirow[b]{2}{*}{ Study or Subgroup } & \multicolumn{3}{|c|}{ Experimental } & \multicolumn{2}{|c|}{ Control } & \multirow{2}{*}{\multicolumn{2}{|c|}{ Total Weight }} & \multirow{2}{*}{$\begin{array}{l}\text { Mean Difference } \\
\text { IV.Random. } 95 \% \mathrm{Cl}\end{array}$} & \multirow{2}{*}{\multicolumn{2}{|c|}{$\begin{array}{c}\text { Mean Difference } \\
\text { IV. Random, } 95 \% \mathrm{Cl}\end{array}$}} \\
\hline & Mean & SD & Total & Mean & SD & & & & & \\
\hline 2016 Yang & 19.47 & 4.22 & 21 & 24.85 & 4.13 & 21 & $6.5 \%$ & $-5.38[-7.91,-2.85]$ & & \\
\hline 2018 Sun & 10.89 & 3.02 & 54 & 15.42 & 2.89 & 54 & $33.5 \%$ & $-4.53[-5.64,-3.42]$ & $\rightarrow-$ & \\
\hline $2018 \operatorname{Tan}$ & 15.04 & 2.82 & 40 & 20.91 & 3.26 & 40 & $23.4 \%$ & $-5.87[-7.21,-4.53]$ & $\rightarrow-$ & \\
\hline 2020 Chen & 13.44 & 2.39 & 50 & 18.87 & 3.02 & 50 & $36.6 \%$ & $-5.43[-6.50,-4.36]$ & - & \\
\hline Total $(95 \% \mathrm{Cl})$ & & & 165 & & & 165 & $100.0 \%$ & $-5.23[-5.87,-4.58]$ & $\bullet$ & \\
\hline $\begin{array}{l}\text { Heterogeneity: Tau }{ }^{2} \\
\text { Test for overall effec }\end{array}$ & $\begin{array}{l}0.00 ; C l \\
Z=15.8\end{array}$ & $\begin{array}{l}\mathrm{ni}^{2}=2 . \\
7(\mathrm{P}<\end{array}$ & $\begin{array}{l}54, \mathrm{df}= \\
0.0000\end{array}$ & $\begin{array}{l}=3(P= \\
11)\end{array}$ & $0.47)$ & $=0 \%$ & & & $\begin{array}{cc}1 & -1 \\
& -5 \\
\text { Favours [experimental }\end{array}$ & $\begin{array}{lcc}0 & 5 & 10 \\
1] & \text { Favours [control] }\end{array}$ \\
\hline
\end{tabular}

(c) UA

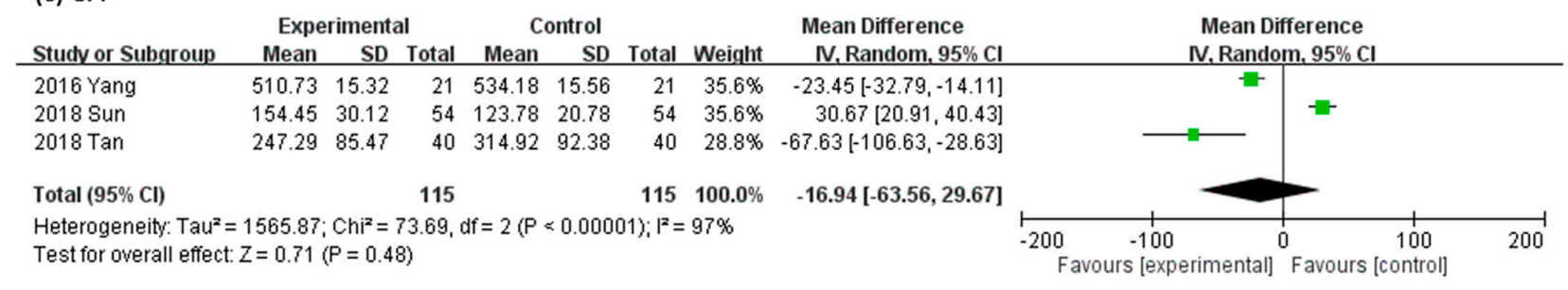

Figure 6. Forest plot for comparison of the serum level of (a) serum creatinine (SCr), (b) blood urea nitrogen (BUN), and (c) uric acid (UA) in patients with uremic pruritus treated with uremic clearance granules. CI, confidence interval.

\subsubsection{Effect of UCG on Serum Levels of Inflammatory Biomarkers}

In Figure 7, the effect of UCG supplementation on the serum levels of inflammatory biomarkers was evaluated as follows: high-sensitivity C-reactive protein (hs-CRP) in six RCTs, $\beta 2-M G$ in four RCTs, TNF- $\alpha$ and IL-6 in two trials. Results of our meta-analyses revealed that UCG supplementation significantly reduced the serum levels of hs-CRP (MD, $-2.07 \mathrm{mg} / \mathrm{dL} ; 95 \% \mathrm{CI},-2.89$ to $-1.25 ; p<0.00001), \beta 2-\mathrm{MG}(\mathrm{MD},-10.18 \mathrm{mg} / \mathrm{L} ; 95 \%$ CI, -15.43 to $-4.93 ; p<0.00001)$, TNF- $\alpha$ (MD, $-15.23 \mathrm{mg} / \mathrm{L} ; 95 \% \mathrm{CI},-20.00$ to -10.47 ; $p<0.00001$ ), and IL-6 (MD, $-6.13 \mathrm{mg} / \mathrm{L} ; 95 \% \mathrm{CI},-7.42$ to $-4.84 ; p<0.00001)$. Heterogeneity across trials was high for hs-CRP $\left(I^{2}=91 \% ; p<0.00001\right)$ and $\beta 2-\mathrm{MG}\left(I^{2}=95 \%\right.$; $p<0.00001)$, but low for TNF- $\alpha\left(I^{2}=6 \% ; p=0.30\right)$ and IL-6 $\left(I^{2}=0 \% ; p=0.52\right)$. 
(a) hs-CRP

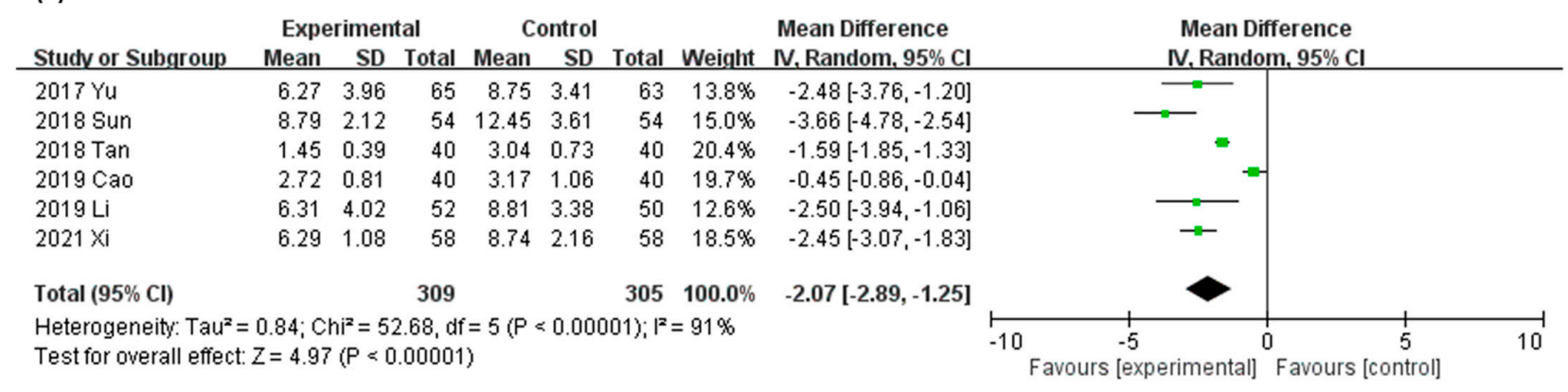

(b) TNF- $\alpha$

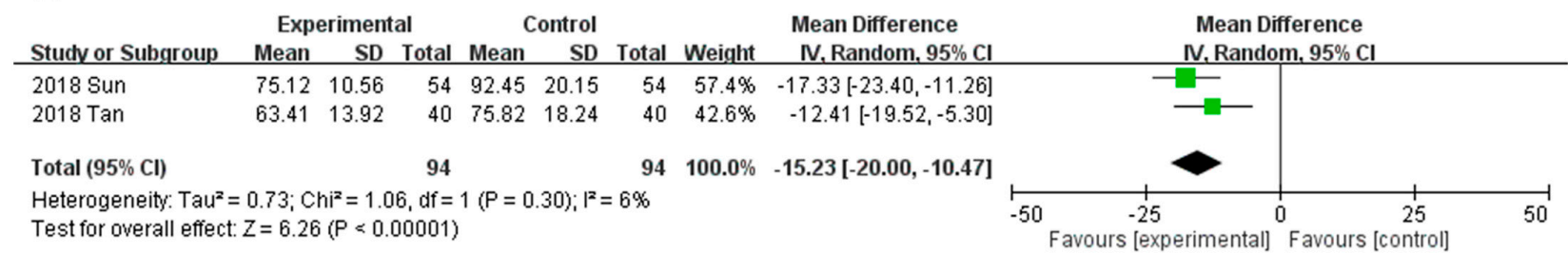

(c) $32-\mathrm{MG}$

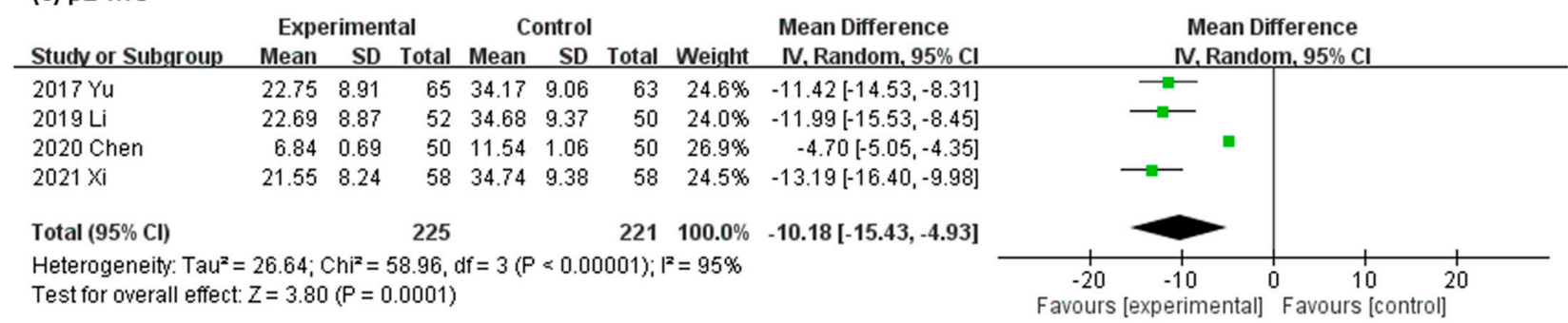

(d) IL-6

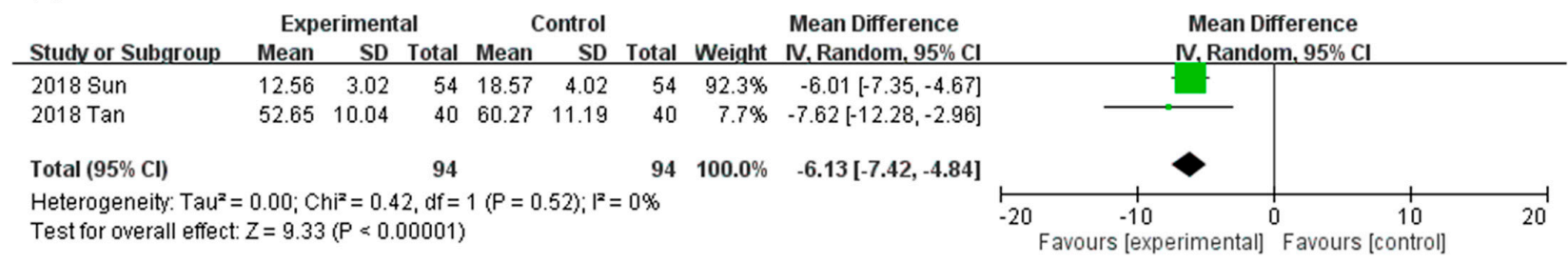

Figure 7. Forest plot for comparison of the serum level of inflammation biomarkers (a) high-sensitivity C-reactive protein (hs-CRP), (b) tumor necrosis factor- $\alpha$ (TNF- $\alpha$ ), (c) $\beta 2$-microglobulin ( $\beta 2-\mathrm{M})$, and (d) interleukin-6 (IL-6) in patients with uremic pruritus treated with uremic clearance granules. $\mathrm{CI}$, confidence interval.

\subsection{Quality of Evidence}

Given the high risk of bias for the primary outcomes, the quality of evidence was low for UCG administration in UP patients (Table S2).

\section{Discussion}

Our meta-analysis suggests that UCG administration significantly reduces the VAS score and improves the overall effectiveness rate. UCG supplementation also significantly decreases the BUN, Scr, PTH, iPTH, and serum P levels and reduces the inflammatory biomarkers. However, further studies with larger sample sizes and rigorous designs focusing on different dosages and routes of UCG supplementation in patients on both HD and PD are recommended. Our meta-analysis revealed that UCG administration significantly reduced the VAS score and improved the overall effectiveness rate. The serum levels of P, PTH, iPTH, Scr, and BUN decreased significantly. Only one of ten studies in 
our meta-analysis reported an adverse effect, although no statistical significance was seen in comparison with the control group. UCG supplementation improves outcomes with regard to inflammatory biomarkers, $\mathrm{P}, \mathrm{PTH}, \mathrm{iPTH}, \mathrm{Scr}$, and BUN levels and reduces the itching sensation.

Systemic inflammation caused by pruritogens (accumulated uremic toxins, histamines, and proinflammatory cytokines) and the imbalance of the opioid system are considered to be possible pathogenesis of UP $[5,50]$. The accumulated uremic toxins can destroy the intestinal barrier integrity, cause dysbiosis of the gut, and progressive kidney damage $[50,51]$. Toxins, including mineral products and uremic toxins, were proposed as pruritogens [4]. Previous studies have also proposed that UP is associated with abnormal mineral metabolism (e.g., higher serum Ca, P, ferritin, and PTH levels) [3,6,52,53]; however, recent studies reported conflicting results [4]. The study by Rayner et al. showed that older age, higher CRP level, low serum albumin level, and presence of hepatitis B or C were associated with a higher risk of developing an itchy skin, and UP was not associated with serum P, Ca, PTH, Kt/V, and hemodiafiltration [54]. Ozen et al. also reported no association between UP and mineral metabolism [55]. In addition, $\beta 2-\mathrm{MG}$ has been considered an inflammatory factor [56] and a pruritogen, eliciting itch-related responses [57]. One study found that patients with uremia had elevated IL-6, TNF- $\alpha$, and CRP levels [58]. Kimmel et al. reported that serum CRP, IL6, and TNF- $\alpha$ levels were higher in patients on HD with UP than in those without UP [9]. The serum hs-CRP level and the severity of pruritus are lower among patients with UP who are vegetarian or switched to a vegetarian diet [59]. Studies have also shown that administering omega-3 to patients on HD reduces serum hs-CRP levels [60] and pruritus scores [61]. The aforementioned findings suggest that UP is associated with microinflammation in the skin or systemic inflammation [4]. In our meta-analysis, administration of UCG to patients with UP significantly decreased the metabolic biomarker levels (e.g., Scr, BUN, P, and PTH) and inflammatory markers (e.g., hs-CRP, TNF- $\alpha, \beta 2-\mathrm{MG}$, and IL-6). The importance of inflammation and proinflammatory factors in patients with UP needs further investigation.

In addition, oral activated charcoal and hemoperfusion could lower uremic toxins and change the microbiota [50]. TCM also showed the ability to reduce different kinds of uremic toxins and modulate intestinal microbiota [51]. UCG can reduce Scr levels [15], resolve Ca and P metabolic dysfunction [22], and improve systemic microinflammation [23] to delay CKD progression. A meta-analysis revealed that in patients with CKD III-V receiving UCG, the Scr, triglyceride, cholesterol levels could be reduced and the hemoglobin level and glomerular filtration rate could be increased [62]. Administration of UCG decreased the serum protein-bound uremic toxins such as indoxyl sulfate and p-cresyl sulfate in patients with ESRD by modifying intestinal microbiota or reducing kidney oxidative stress and inflammation $[63,64]$. Rhubarb, an ingredient in UCG, showed the benefit of gut microbiota modulation and inflammation alleviation enhancing the amount of probiotic Lactobacillus and short-chain fatty acid-producing bacteria [65].

In the rat renal failure model, UCG showed a renoprotective effect; it could promote extracellular matrix degradation and regulate MMP-2/TIMP-1 balance or signal molecular activity of the TGF- $\beta$ /Smad pathway to alleviate renal dysfunction and tubulointerstitial fibrosis [66]. UCG could decrease renal fibrosis and anemia in CKD rats by regulating the transforming growth factor- $\beta$ (TGF- $\beta$ ) and erythropoietin signaling pathways. These pharmacologic results were consistent with in silico predictions [16].

Among the RCTs included in our study, UCG dosage varied from 5 to $20 \mathrm{~g} /$ day for oral and $30 \mathrm{~g} /$ day for enema administration; moreover, the treatment duration also varied from one month to three months for oral and 18 months for enema. The overall effectiveness of oral and enema UCG was similar in our study $(75.0 \%-95.0 \%$ vs. $87.5 \%)$ [24,40-43,45,48,49]. In another RCT on UP therapy, the enema UCG group showed a higher overall effectiveness rate than the oral UCG group (74.19\% vs. 41.94\%) [67]. Although RCTs have demonstrated the beneficial effects of UCG supplementation, the optimal dosage, route, and duration of 
administration remain unclear. The study by Tan used UCG along with HD and HP and showed a better antipruritic effect than the control group receiving only HD and HP [45].

The studies included in our meta-analysis showed considerable heterogeneity because of various clinical factors. First, the route, dosage, and duration of UCG differed across the studies. Second, some discrepancies in the interventions of the control groups existed. Most of the trials used HD [24,40,42-44,48,49], two mn trials used HD and HP [45,47], and another trial used HD, oral Caltrate D600, and Calcitriol [41]. Finally, outcomes of overall effectiveness rate were measured using different pruritus scales. These inconsistencies between trials resulted in heterogeneity. No significant heterogeneity was seen across trials in VAS, overall effectiveness rate, P, BUN, TNF- $\alpha$, and IL-6. This study has some limitations. First, the included RCTs had small sample sizes. The method of randomization was unclear, and no trial reported double blinding. For pruritus evaluation, more detailed and multidimensional pruritus assessments considering not only pruritus severity and direction but also life quality such as 5D-IS and 12-item pruritus severity scale are needed [68-70]. Uniform pruritus scale is better for comparison of therapeutic effect.

\section{Conclusions}

Our meta-analysis suggests that UCG administration significantly reduces the VAS score and improves the overall effectiveness rate. UCG supplementation also significantly decreases the BUN, Scr, PTH, iPTH, and serum P levels and reduces the inflammatory biomarkers. However, further studies with larger sample sizes and rigorous designs focusing on different dosages and routes of UCG supplementation in patients on both HD and PD are recommended.

\section{Materials and Methods}

\subsection{Literature Search}

Articles published until 19 July 2021 were searched for on the PubMed, Embase, Cochrane Library, CINAHL, ClinicalTrials.gov, Chinese National Knowledge Infrastructure, Airiti Library, and Wanfang databases. The MeSH and Emtree search headings were used as follows: uremic clearance granule, pruritus, uremic, chronic kidney disease, dialysis, and their synonyms. We conducted free-text search using these terms and their combinations. To broaden the search, we also reviewed all the retrieved articles and citations using the "related articles" facility on PubMed. Furthermore, we parsed the cited studies in the accessed papers manually and contacted known experts of the field to identify other studies. Finally, unpublished studies were inspected from the ClinicalTrials.gov registry (http:/ / clinicaltrials.gov/ (accessed on 19 July 2021)). The search was not restricted by language. This systematic review was accepted by the online PROSPERO of the National Institute for Health Research (CRD 42020199834). The complete search strategy is described in the supplement (Table S3).

\subsection{Study Selection}

RCTs were selected to evaluate the efficacy of UCG in UP patients. The inclusion criteria were as follows: the presence of UP, administration of UCG, and availability of quantitative data for pruritus severity. We excluded studies wherein UP was not diagnosed. We included studies regardless of the pruritus evaluation methods. When raw or missing data were required, we contacted the authors by email. We selected the study with the larger population when duplicate studies published using overlapping data sets.

\subsection{Data Extraction and Quality Assessment}

Two authors extracted the following information from each article independently: publication details, study design, inclusion and exclusion criteria, matching criteria, sample size, age, intervention period, route, dosage and frequency of UCG and placebo, pruritus severity assessment tool, quantification of pruritus severity, renal function, inflammation biomarkers, serum levels of $\mathrm{Ca}, \mathrm{P}, \mathrm{PTH}$, and $\mathrm{iPTH}$, and the overall effectiveness 
rate. The selected studies were screened for eligibility by two reviewers; subsequently, the aforementioned inclusion criteria were applied. The reviewers reviewed the articles independently and compared the results; discrepancy was resolved by a third reviewer. The quality of the studies was evaluated using the "risk of bias" method recommended by the Cochrane Collaboration [71].

\subsection{Data Synthesis and Analysis}

The efficacy of UCGs was evaluated using outcome measures described herein. The primary outcomes included mean differences in VAS scores and the OR of the overall effectiveness rate. Secondary outcomes included the mean differences in serum Ca, P, PTH, and iPTH levels; renal function indexes; and inflammation biomarkers. We conducted the analysis using RevMan 5.4 (Cochrane Collaboration, Copenhagen, Denmark). A metaanalysis was conducted according to recommendations in the PRISMA guidelines. We used the OR as the summary statistic to analyze the dichotomous outcomes and used the weighted mean difference (WMD) to analyze the continuous outcomes. Both the summary statistics were reported with $95 \%$ confidence intervals (CIs). The random-effect model was used to pool OR and WMD estimates if studies were statistically heterogeneous. The $I^{2}$ test and Cochran Q statistic were used to assess heterogeneity among studies. The pooled estimates were considered to show significant heterogeneity when $I^{2}>50 \%$ or $p<0.1$. The quality of evidence was assessed using the Guideline Development Tool developed by the GRADE Working Group [72].

Supplementary Materials: The following are available online at https:/ /www.mdpi.com/article/10 .3390/toxins13100702/s1, Table S1: Characteristics of Selected Studies with inspection data, Table S2: Grade profile summary of 'UCG for UP' quality assessment, Table S3: Search History.

Author Contributions: All authors contributed to this review article. P.-H.L. (Po-Hsuan Lu) designed the study. P.-H.L. (Ping-Hsun Lu), H.-E.C., and J.-Y.W. contributed to the literature search, data extraction, quality assessment, and writing the first draft of the article. P.-H.L. (Ping-Hsun Lu) performed statistical analysis and interpreted the results. P.-H.L. (Po-Hsuan Lu) critically revised the manuscript. All authors have read and agreed to the published version of the manuscript.

Funding: This research received no external funding.

Institutional Review Board Statement: Not applicable.

Informed Consent Statement: Not applicable.

Data Availability Statement: The data used to support the findings of this study are included within the article or Supplementary Materials.

Acknowledgments: The authors thank Mackay Memorial Hospital, Taipei Tzu Chi Hospital, and the participants for their contribution to the study.

Conflicts of Interest: The authors declare no conflict of interest.

\section{References}

1. Wu, H.Y.; Peng, Y.S.; Chen, H.Y.; Tsai, W.C.; Yang, J.Y.; Hsu, S.P.; Pai, M.F.; Lu, H.M.; Chiang, J.F.; Ko, M.J.; et al. A Comparison of Uremic Pruritus in Patients Receiving Peritoneal Dialysis and Hemodialysis. Medicine 2016, 95, e2935. [CrossRef] [PubMed]

2. Mathur, V.S.; Lindberg, J.; Germain, M.; Block, G.; Tumlin, J.; Smith, M.; Grewal, M.; McGuire, D.; Investigators, I.N.R. A longitudinal study of uremic pruritus in hemodialysis patients. Clin. J. Am. Soc. Nephrol. 2010, 5, 1410-1419. [CrossRef] [PubMed]

3. Narita, I.; Alchi, B.; Omori, K.; Sato, F.; Ajiro, J.; Saga, D.; Kondo, D.; Skatsume, M.; Maruyama, S.; Kazama, J.J.; et al. Etiology and prognostic significance of severe uremic pruritus in chronic hemodialysis patients. Kidney Int. 2006, 69, 1626-1632. [CrossRef] [PubMed]

4. Verduzco, H.A.; Shirazian, S. CKD-Associated Pruritus: New Insights into Diagnosis, Pathogenesis, and Management. Kidney Int. Rep. 2020, 5, 1387-1402. [CrossRef] [PubMed]

5. Lu, P.-H.; Tai, Y.-C.; Yu, M.-C.; Lin, I.-H.; Kuo, K.-L. Western and complementary alternative medicine treatment of uremic pruritus: A literature review. Tzu Chi Med. J. 2021, 33, 350-358. [CrossRef]

6. Ramakrishnan, K.; Bond, T.C.; Claxton, A.; Sood, V.C.; Kootsikas, M.; Agnese, W.; Sibbel, S. Clinical characteristics and outcomes of end-stage renal disease patients with self-reported pruritus symptoms. Int. J. Nephrol. Renov. Dis. 2013, 7, 1-12. [CrossRef] 
7. Chen, H.-Y.; Chiu, Y.-L.; Hsu, S.-P.; Pai, M.-F.; Lai, C.-F.; Yang, J.-Y.; Peng, Y.-S.; Tsai, T.-J.; Wu, K.-D. Elevated C-reactive protein level in hemodialysis patients with moderate/severe uremic pruritus: A potential mediator of high overall mortality. QJM Int. J. Med. 2010, 103, 837-846. [CrossRef]

8. Fallahzadeh, M.K.; Roozbeh, J.; Geramizadeh, B.; Namazi, M.R. Interleukin-2 serum levels are elevated in patients with uremic pruritus: A novel finding with practical implications. Nephrol. Dial. Transplant. 2011, 26, 3338-3344. [CrossRef]

9. Kimmel, M.; Alscher, D.M.; Dunst, R.; Braun, N.; Machleidt, C.; Kiefer, T.; Stülten, C.; van der Kuip, H.; Pauli-Magnus, C.; Raub, U. The role of micro-inflammation in the pathogenesis of uraemic pruritus in haemodialysis patients. Nephrol. Dial. Transplant. 2006, 21, 749-755. [CrossRef]

10. Jaiswal, D.; Uzans, D.; Hayden, J.; Kiberd, B.A.; Tennankore, K.K. Targeting the Opioid Pathway for Uremic Pruritus: A Systematic Review and Meta-analysis. Can. J. Kidney Health Dis. 2016, 3, 2054358116675345. [CrossRef]

11. Eusebio-Alpapara, K.M.V.; Castillo, R.L.; Dofitas, B.L. Gabapentin for uremic pruritus: A systematic review of randomized controlled trials. Int. J. Dermatol. 2019, 59, 412-422. [CrossRef] [PubMed]

12. Badiee Aval, S.; Ravanshad, Y.; Azarfar, A.; Mehrad-Majd, H.; Torabi, S.; Ravanshad, S. A Systematic Review and Meta-analysis of Using Acupuncture and Acupressure for Uremic Pruritus. Iran. J. Kidney Dis. 2018, 12, 78-83. [PubMed]

13. Xue, W.; Zhao, Y.; Yuan, M.; Zhao, Z. Chinese herbal bath therapy for the treatment of uremic pruritus: Meta-analysis of randomized controlled trials. BMC Complement. Altern. Med. 2019, 19, 103. [CrossRef] [PubMed]

14. Pakfetrat, M.; Basiri, F.; Malekmakan, L.; Roozbeh, J. Effects of turmeric on uremic pruritus in end stage renal disease patients: A double-blind randomized clinical trial. J. Nephrol. 2014, 27, 203-207. [CrossRef] [PubMed]

15. Zheng, Y.; Cai, G.-Y.; He, L.-Q.; Lin, H.-L.; Cheng, X.-H.; Wang, N.-S.; Jian, G.-H.; Liu, X.-S.; Liu, Y.-N.; Ni, Z.-H. Efficacy and safety of Niaoduqing particles for delaying moderate-to-severe renal dysfunction: A randomized, double-blind, placebo-controlled, multicenter clinical study. Chin. Med. J. 2017, 130, 2402. [CrossRef] [PubMed]

16. Wang, X.; Yu, S.; Jia, Q.; Chen, L.; Zhong, J.; Pan, Y.; Shen, P.; Shen, Y.; Wang, S.; Wei, Z. NiaoDuQing granules relieve chronic kidney disease symptoms by decreasing renal fibrosis and anemia. Oncotarget 2017, 8, 55920-55937. [CrossRef]

17. Sun, Y.; Yin, Q.; Hui, Y.D. Analysis of TCM Treatment of Hemodialysis Complications of Uremia. J. Basic Chin. Med. 2017, 23, 1269-1271.

18. Wang, Z.X. Observation on the clinical therapeutic effect of modified Guomin decoction to treat uremic pruritus. World Latest Med. Inf. 2017, 17, 69-70.

19. Zhang, J.; Li, J.; Zhang, H.-L.; Qu, H.-S.; Zhang, X.-Z.; Cheng, Y.-Q.; Zhang, Z.-M.; Huang, J.-Q. Meta-analysis of niaoduqing granules combined with raas system blocker in the treatment of diabetic nephropathy. World J. Tradit. Chin. Med. $2019,5,193$.

20. Huang, L.; Xie, D.; Yu, Y.; Liu, H.; Shi, Y.; Shi, T.; Wen, C. TCMID 2.0: A comprehensive resource for TCM. Nucleic Acids Res. 2017, 46, D1117-D1120. [CrossRef]

21. Feng, Q.; Wan, Y.; Jiang, C.; Wang, C.; Wei, Q.; Zhao, Q. The mechanism and effect of TCM in delaying the progression of chronic renal failure. Chin. J. Tradit Chin. Med. 2011, 36, 1122-1128.

22. Ye, M.-Y.; Zheng, J.; Zhang, J. The Influence of Niaoduqing Particle on the Calcium and Phosphorus Metabolism and FGF23 in Patients with Chronic Kidney Disease. Med. Innov. China 2015, 23, 16-18.

23. Yin, X.-F.; Han, L.-L. Effect of uremic clearance granule on the systemic micro-inflammatory state of patients after peritoneal dialysis. Pract. Pharm. Clin. Remedies 2013, 2, 125-126.

24. Chen, X.; Li, L.J.; Wu, D. A clinical study on uremic clearance granule combined with high-flux hemodialysis in treating uremia pruritus. China Pharm. 2020, 4, 63-65.

25. Mettang, T.; Pauli-Magnus, C. The pathophysiological puzzle of uremic pruritus - Insights and speculations from therapeutic and epidemiological studies. Perit. Dial. Int. 2000, 20, 493-494. [CrossRef] [PubMed]

26. Saito, A. Challenge for developing more complete renal replacement technologies in Japan. Blood Purif. 2013, 34, 255. [CrossRef]

27. Chen, L.M.; Zhao, Y.D.; Wang, T.T.; Huang, B.B.; Liu, X.Q. Research progress of Niaoduqing granules in treating chronic kidney disease. J. MuDanJiang Med. Univ. 2019, 40, 127-129.

28. Tang, N.; Zhang, X.H. Study on improving effect of Niaoduqing on PTH and micro-inflammatory state in MHD Patients. J. Chin. Med. Mater. 2017, 40, 718-720.

29. Chu, X.Y. Clinical observation of Niaoduqing granule combined with calcitriol in the treatment of pruritus in dialysis patients. Master's Thesis, Zhejiang Chinese Medical University, Hangzhou, China, 1 June 2013.

30. Chu, X.Y.; Jiang, A.L.; Zhang, J.P.; Sun, Y. Clinical observation of Niaoduqing granule combined with calcitriol in the treatment of pruritus in dialysis patients. Chin. J. Integr. Tradit. West. Nephrol. 2012, 9, 825-826.

31. Dai, W.X.; Li, W.C. Observation on the treatment of hyperphosphatemia complicated with skin itching in hemodialysis patients. Healthmust-Readmagazine 2018, 3, 113.

32. Guo, K.P.; Yu, K.; Fu, Y.; Wang, J. Clinical observation and nursing experience of treating uremic pruritus by traditional Chinese medicine soaking and washing combined oral treatment. Cardiovasc. Dis. J. Integr. Tradit. Chin. West. Med. 2018, 6, 150-151.

33. Ji, X. To study the effect of Niaoduqing granule combined with hemodialysis in uremic patients to improve nutrition and protect renal function. Electron. J. Clin. Med. Lit. 2019, 6, 32-33.

34. Men, W.J.; Ding, Z.M. Effect of Niaoduqing particles on calcium-phosphorus metabolism and parathyroid hormone in patients of end-stage renal failure with maintenance hemodialysis. China Med. 2015, 10, 1818-1821. 
35. Pao, C.M.; Zhao, S.P.; Yuan, J.; Tian, H. Effects of Niaoduqing granules on end-stage renal failure on maintenance hemodialysis patients with calcium phosphorus metabolism and parathyroid hormone levels. China Health Stand. Manag. 2016, 7, 130-131.

36. Tang, J.; Wang, L.; Lu, Q.Z.; Zeng, Y.Y.; Sun, Q.L. Nursing care of colon dialysis combined with Niaoduqing granules in the treatment of early and mid-term chronic renal failure. Guizhou Med. J. 2012, 36, 856-857.

37. Xia, Y.; Zhou, J.J. Observation of Chinese medicine enema on PTH clears in blood for patients of chronic kidney disease. Hebei Tradit. Chin. Med. 2014, 36, 1466-1468.

38. Xu, L.F. Analysis of curative effect of Niaoduqing granules in treating chronic renal failure. Qinghai Med. J. 2018, $10,13-14$.

39. Wang, C.P.; Lu, Y.C.; Tsai, I.T.; Tang, W.H.; Hsu, C.C.; Hung, W.C.; Yu, T.H.; Chen, S.C.; Chung, F.M.; Lee, Y.J.; et al. Increased Levels of Total p-Cresylsulfate Are Associated with Pruritus in Patients with Chronic Kidney Disease. Dermatology 2016, 232, 363-370. [CrossRef]

40. Cao, Y.G. Clinical Observation of Niaoduqing Granule Combined with High Flux Hemodialysis in Treating Uremic Pruritus. Chin. Med. Mod. Distance Educ. China 2019, 2, 117-118.

41. Kuo, X.W.; Li, X.; Guo, W.J. Study on the Efficacy of Niaoduqing Granules in Treating Pruritus and Removing Blood Toxin in Hemodialysis Patients. Clin. Med. Eng. 2019, 4, 485-486.

42. Kun, D.Z.; Yu, S.J.; Li, M. The feasibility of Niaoduqing granule in adjuvant treatment of uremic pruritus. World Latest Med. Inf. 2019, 19, 182-183.

43. Li, X.; Kuo, X.W. The feasibility of Niaoduqing granule in adjuvant treatment of uremic pruritus. Jilin Med. J. $2019,1,91$.

44. Sun, J.K.; Chen, J. Hemodialysis for uremic patients with Niaoduqing inflammation and itch of skin effect. Mod. Med. Health Res. 2018, 7, 1-4.

45. Tan, H.J. Clinical observation of Niaoduqing granule assisted low-frequency hemoperfusion combined with hemodialysis in the treatment of pruritus in patients with uremia. Chin. J. Integr. Tradit. West. Nephrol. 2018, 12, 1099-1101.

46. Xi, M.M. Clinical Observation of Niaoduqing Granules Combined with High-flux Hemodialysis in Treating Uremic Skin Pruritus. Guide China Med. 2021, 19, 112-113.

47. Yang, Y.L. The influence of Niaoduqing particle on uremic pruritus in maintenance hemodialysis patients. Master's Thesis, Hubei University of Chinese Medicine, Wuhan, China, 27 May 2016.

48. Yu, D.; Li, L.Z.; Zhang, S.Y. Clinical effect of niaoduqing particle combined with high-flux hemodialysis in the treatment of patients with uremic pruritus. Pract. J. Clin. Med. 2017, 6, 204-206.

49. Kao, C.M.; Li, J.H. The observation on the efficacy of Niaoduqing retention enema combined with low-frequency hemoperfusion and hemodialysis on uremia pruritus. China Health Care Nutr. 2012, 22, 1846-1847. [CrossRef]

50. Cupisti, A.; Piccoli, G.B.; Gallieni, M. Charcoal for the management of pruritus and uremic toxins in patients with chronic kidney disease. Curr. Opin. Nephrol. Hypertens 2020, 29, 71-79. [CrossRef] [PubMed]

51. Lu, P.-H.; Yu, M.-C.; Wei, M.-J.; Kuo, K.-L. The Therapeutic Strategies for Uremic Toxins Control in Chronic Kidney Disease. Toxins 2021, 13, 573. [CrossRef] [PubMed]

52. Pisoni, R.L.; Wikström, B.; Elder, S.J.; Akizawa, T.; Asano, Y.; Keen, M.L.; Saran, R.; Mendelssohn, D.C.; Young, E.W.; Port, F.K. Pruritus in haemodialysis patients: International results from the Dialysis Outcomes and Practice Patterns Study (DOPPS). Nephrol. Dial. Transplant. 2006, 21, 3495-3505. [CrossRef]

53. Kimata, N.; Fuller, D.S.; Saito, A.; Akizawa, T.; Fukuhara, S.; Pisoni, R.L.; Robinson, B.M.; Akiba, T. Pruritus in hemodialysis patients: Results from the Japanese Dialysis Outcomes and Practice Patterns Study (JDOPPS). Hemodial. Int. 2014, 18, 657-667. [CrossRef] [PubMed]

54. Rayner, H.C.; Larkina, M.; Wang, M.; Graham-Brown, M.; van der Veer, S.N.; Ecder, T.; Hasegawa, T.; Kleophas, W.; Bieber, B.A.; Tentori, F.; et al. International Comparisons of Prevalence, Awareness, and Treatment of Pruritus in People on Hemodialysis. Clin. J. Am. Soc. Nephrol. 2017, 12, 2000-2007. [CrossRef] [PubMed]

55. Ozen, N.; Cinar, F.I.; Askin, D.; Mut, D. Uremic pruritus and associated factors in hemodialysis patients: A multi-center study. Kidney Res. Clin. Pract. 2018, 37, 138-147. [CrossRef] [PubMed]

56. Vanholder, R.; Pletinck, A.; Schepers, E.; Glorieux, G. Biochemical and Clinical Impact of Organic Uremic Retention Solutes: A Comprehensive Update. Toxins 2018, 10, 33. [CrossRef] [PubMed]

57. Andoh, T.; Maki, T.; Li, S.; Uta, D. $\beta 2-$ Microglobulin elicits itch-related responses in mice through the direct activation of primary afferent neurons expressing transient receptor potential vanilloid 1. Eur. J. Pharmacol. 2017, 810, 134-140. [CrossRef] [PubMed]

58. Kaysen, G.A. The microinflammatory state in uremia: Causes and potential consequences. J. Am. Soc. Nephrol. 2001, 12, 1549-1557. [CrossRef]

59. Tseng, C.Y.; Wu, T.T.; Lai, C.W.; Lin, H.J.; Chou, C.Y.; Chang, C.T.; Chen, H.C. Vegetarian diet may ameliorate uremic pruritus in hemodialysis patients. Ren. Fail. 2018, 40, 514-519. [CrossRef]

60. Dezfouli, M.; Moeinzadeh, F.; Taheri, S.; Feizi, A. The Effect of Omega-3 Supplementation on Serum Levels of Inflammatory Biomarkers and Albumin in Hemodialysis Patients: A Systematic Review and Meta-analysis. J. Ren. Nutr. 2020, 30, 182-188. [CrossRef]

61. Shayanpour, S.; Beladi Mousavi, S.S.; Lakhaye Rizi, P.; Cheraghian, B. The effect of the omega-3 supplement on uremic pruritus in hemodialysis patients; a double-blind randomized controlled clinical trial. J. Nephropathol. 2017, 8, 13. [CrossRef]

62. Yin, J.Z.; Zhu, B.; Chen, H.Y.; Li, P.; Lu, J.C.; Yan, M.H.; Li, P. Meta-analysis of Niaoduqing granules in the treatment of chronic kidney disease stages 3 5. Chin. J. Integr. Tradit. West. Nephrol. 2020, 21, 136-142. 
63. Liu, M.; Zhu, J. Effects of hemodialysis combined with uremic clearance granule on serum protein-bound uremic toxins in patients with end-stage renal disease. Chin. J. Prim. Med. Pharm. 2020, 2613-2617. [CrossRef]

64. Ji, C.; Deng, Y.; Yang, A.; Lu, Z.; Chen, Y.; Liu, X.; Han, L.; Zou, C. Rhubarb Enema Improved Colon Mucosal Barrier Injury in $5 / 6$ Nephrectomy Rats May Associate With Gut Microbiota Modification. Front. Pharmacol. 2020, 11, 1092. [CrossRef]

65. Cui, H.-X.; Zhang, L.-S.; Luo, Y.; Yuan, K.; Huang, Z.-Y.; Guo, Y. A Purified Anthraquinone-Glycoside Preparation From Rhubarb Ameliorates Type 2 Diabetes Mellitus by Modulating the Gut Microbiota and Reducing Inflammation. Front. Microbiol. 2019, 10. [CrossRef] [PubMed]

66. Huang, Y.R.; Wei, Q.X.; Wan, Y.G.; Sun, W.; Mao, Z.M.; Chen, H.L.; Meng, X.J.; Shi, X.M.; Tu, Y.; Zhu, Q. Ureic clearance granule, alleviates renal dysfunction and tubulointerstitial fibrosis by promoting extracellular matrix degradation in renal failure rats, compared with enalapril. J. Ethnopharmacol. 2014, 155, 1541-1552. [CrossRef] [PubMed]

67. Wu, Y.; Xu, C.W.; Li, H. Observation of curative effect of Niaoduqing enema in treating uremic pruritus. Tianjin Med. J. 2011, 39, 272-274.

68. Reich, A.; Bożek, A.; Janiszewska, K.; Szepietowski, J.C. 12-Item Pruritus Severity Scale: Development and Validation of New Itch Severity Questionnaire. BioMed Res. Int. 2017, 2017, 3896423. [CrossRef] [PubMed]

69. Altinok Ersoy, N.; Akyar, I. Multidimensional pruritus assessment in hemodialysis patients. BMC Nephrol. 2019, 20, 42. [CrossRef]

70. Esmaeili, A.; Abbasi, M.R.; Namazi, S. Validity and reliability of a Persian version of the 12-Item Pruritus Severity Scale in hemodialysis patients with uremic pruritus. Iran. J. Dermatol. 2021, 24, 73-79.

71. Higgins, J.P.; Thomas, J.; Chandler, J.; Cumpston, M.; Li, T.; Page, M.J.; Welch, V.A. (Eds.) Cochrane Handbook for Systematic Reviews of Interventions, 2nd ed.; Cochrane: Chichester, UK; John Wiley \& Sons: Hoboken, NJ, USA, 2019.

72. GRADEpro, GDT. Gradepro guideline development tool [software]. McMaster University 2015. p. 435. Available online: https:/ /gradepro.org/ (accessed on 19 July 2021). 